\title{
TOURISM BUSINESS RESPONSES TO SOUTH AFRICA'S COVID-19 PANDEMIC EMERGENCY
}

\author{
Jayne M. ROGERSON ${ }^{*}$ \\ University of Johannesburg, School of Tourism \& Hospitality, Johannesburg, South Africa, e-mail: jayner@uj.ac.za
}

\begin{abstract}
Citation: Rogerson, J.M. (2021). TOURISM BUSINESS RESPONSES TO SOUTH AFRICA'S COVID-19 PANDEMIC EMERGENCY. GeoJournal of Tourism and Geosites, 35(2), 338-347. https://doi.org/10.30892/gtg.35211-657
\end{abstract}

\begin{abstract}
The COVID-19 pandemic has compelled tourism businesses to rapidly adjust operations in newer and more resilient ways as firms have to change priorities and respond to challenges, including of shifts in consumer demand. Extant research on tourism business responses and adaptations to COVID-19 highlights the significance of organizational resilience and ability of businesses to respond to uncertainty. Using a qualitative approach this paper investigates tourism business responses in South Africa, seemingly the country worst hit on the African continent by the COVID-19 crisis. The research analyses tourism business responses occurring in one of South Africa's tourism-dependent areas and thus most exposed to the radical effects of COVID-19. Key findings are of the self-reliant character of the community of tourism enterprises in and around Overstrand cluster in the Western Cape. Product diversification, reductions of prices, reduced staffing, changed marketing, greater inter-enterprise cooperation are several of the most significant business adjustments undertaken. With the negative financial impacts of COVID19 on local tourism enterprises exacerbated by South African government measures for alcohol bans and beach closures there is evidence of a disconnect and lack of trust between the area's local businesses and national government.
\end{abstract}

Key words: COVID-19, tourism business, adaptation, responses, resilience, South Africa

\section{INTRODUCTION}

The years 2020-2021 will be forever associated with COVID-19. Verma and Gustafsson (2020: 253) contend that COVID-19 "is a human social and economic crisis that has attacked the core of human existence". Currently COVID-19 is the major growth pole in international tourism scholarship (Rogerson and Baum, 2020). Olsen and Timothy (2020: 170) observe that the "COVID-19 pandemic has led to a surge in academic publications focusing on both the immediate impacts of the pandemic on global travel and, more importantly, how the pandemic marks the chance to restart, reset, and reinvigorate tourism in a more sustainable way". This situation is unremarkable as for tourism destinations, the COVID-19 pandemic is one of the most impactful events of the $21^{\text {st }}$ century as it has precipitated an unprecedented crisis with the almost total shutdown of tourist flows (Kock et al., 2020; Zenker and Kock, 2020; Li et al. (2021: 2) summarise the policy response of governments to the COVID-19 crisis into the categories: "infrastructure reconstruction, financial support and human resources for tourism companies and promotion and marketing activities".

Beyond its public health impacts COVID-19 has restructured the landscape for business operations with many businesses closed on a permanent or temporary basis (Bartik, 2020). Tourists perceptions of risk associated with the spread of the pandemic have resulted in changing patterns of mobilities and radical shifts in patterns of consumer demand to which businesses have to adapt (Korinth, 2020; Kowalska and Niezgoda, 2020; Neuburger and Egger, 2020; Sánchez-Cañizares et al., 2020; Godovykh et al., 2021; Rogerson and Rogerson, 2021a). Seemingly, the ways that tourism businesses are confronting and responding to the debilitating effects of the COVID-19 pandemic vary geographically across different regions of the world as is shown by the eight country study undertaken by Alonso et al. (2021a, 2021b).

Africa is one continent that was not included in the rich multi-country research reported by Alonso et al. (2021a, 2021b). The aim in this paper is to address this knowledge gap by examining tourism business responses in South Africa, seemingly the country worst hit on the African continent by the COVID-19 crisis (Rogerson and Rogerson, 2020a, 2020b). More specifically, the research analyses tourism business responses occurring in one of South Africa's tourism-dependent areas and thus most exposed to the radical effects of COVID-19.

\section{LITERATURE REVIEW}

Arguably, the COVID-19 pandemic has changed the prospects of nearly all types of businesses across the world (Kvirkvelia and Tsitsagi, 2021). Verma and Gustafsson (2020: 253) contend that due to COVID-19 pandemic impacts it "is becoming challenging for most businesses across the world to keep their financial wheels rolling, given reduced revenues and the high level of uncertainty". For the sector of tourism businesses Assaf and Scuderi (2020: 731) observe that COVID19 "has been one of the most impactful and tragic pandemics of modern times". The pandemic is unlike many other disasters and crises that previously have impacted the tourism sector and its enterprises (Hall et al., 2020). Seemingly, there will no return to the 'normal' as existed before (Brouder, 2020; Sigala, 2020; Gössling et al., 2021). Activities involving direct contact between consumers and service providers have been most adversely impacted by restrictions imposed on

\footnotetext{
* Corresponding author
} 
movement and social distancing. According to Kock et al. (2020: 2) the pandemic represents "a paradigm shift in research on tourists' behaviour and decision-making" because "what was previously taken for granted may not hold in the COVID19 era" (Kock et al., 2020: 2). The negative effects of the pandemic are especially pronounced in tourist destinations that are economically anchored on tourism. Research is needed most especially on COVID-19 impacts and responses in those localities and regions that are most reliant on tourism (Deb and Nafi, 2020).

Saarinen and Wall-Reinius (2021) identify the consolidation of two differing narratives or schools of thought in the raging contemporary tourism debates about COVID-19. Both narratives highlight the seriousness of the COVID-19 pandemic for global tourism, albeit they differ in terms of what comes or should come next. First, is a 'resilience school of thought' which stresses the historical capacity of the tourism sector to cope with or adapt to shocks such as the global financial crisis, SARS, or natural events such as earthquakes or tsunamis (Saarinen and Wall-Reinius, 2021: 145). The emphasis is upon the sector's capacity to return to pre-crisis growth paths. This perspective is one which is projected by much of the tourism industry and the majority of national governments including the Department of Tourism in South Africa. Second, is a 'readjustment school of thought' which emphasizes the need to re-think the growth at all cost and volume at all cost path for tourism which has dominated in recent years and in part is responsible for the current crisis (Saarinen and Wall-Reinius, 2021: 146). For this second school COVID-19 is a watershed or turning point for tourism and projects that its impacts will be irreversible as it will fundamentally shift the nature of tourism and human mobility into the future (Higgins-Desbiolles, 2020; Sigala, 2020). Carr (2020: 30) avers that the COVID-19 pandemic represents "an opportunity to re-envision our economies, possibly accelerating governments' responses to environmental practices that have negatively impacted nature". For both these schools of thought there is a need for empirical evidence on how tourism businesses are responding to the COVID-19 crisis.

The pandemic has compelled tourism businesses to rapidly operate in newer and more resilient ways as firms have to change priorities and respond to its challenges (Verma and Gustafsson, 2020). At the core of tourism recovery strategies are tourism businesses which include those operated by major corporations as well as smaller family owned operations including lifestyle entrepreneurs (Dias et al., 2021a). In a context wherein many countries are concerned to revitalize their economies and reignite tourism it is essential that greater understanding be developed of the challenges facing these different types of tourism businesses (Dias, 2021b). The significance of organisational resilience, which is essentially defined as an organisation's ability to manage uncertainty, is viewed crucial for the success of tourism businesses (Prayag et al., 2018). As is the case of other disasters in terms of recovery it is argued that "the ability of tourism businesses to overcome COVID-19 will depend on the levels of their organisational resilience" (Bhaskara and Filimonau, 2021; 364). In addition, other critical factors are viewed as the extent of local inter-enterprise cooperation as well as support available from governments (Jiang et al., 2019). Bressan et al. (2021: 1) disclose that in the case of micro and small winery businesses faced with the loss of vital income through decreased demand managers resorted "to exploiting various initiatives, including 'reinventing' their firms". The importance of entrepreneur's proactiveness and resourcefulness was flagged.

Extant research on tourism business responses and adaptations to COVID-19 highlight a number of issues. In research examining youth travel and the responses to COVID-19 of operators of attractions and of youth travel accommodation Richards and Morrill (2021) pinpoint that the most reported action was the modification of cancellation policies. Other responses by enterprises included product diversification including modification and repurposing of properties, reduction of capacity, forming new partnerships, modifying target markets and change in marketing. This said, for many youth travel enterprises it is observed that "these measures were still not sufficient, as many have gone out of business" (Richards and Morrill, 2021: 6). In the work by Alonso et al. (2021a) focused mainly on small and medium-sized tourism and hospitality firms three different ways of business coping with COVID-19 were isolated. First, is a self-reliant approach which involved changes in revenue-generation, reduction in employment hours and staff rotation, and mothballing certain operations. Second, is a vigilant dimension in which businesses prepare for a 'new regime'" and seek to apply for government relief packages. The third approach was that termed the inoperative dimension wherein firms discontinued operations completely and/or waited for new protocols. In a further contribution Alonso et al. (2021b: 10) highlight that in order to cope with the fall-out from COVID-19 "self-reliance and self-initiating steps illustrate the need to revert to the implementation of new forms generating revenues, while seeking to limit costs". Another notable investigation is that by Dias et al. (2021a) on the category of tourism lifestyle entrepreneurs and of their potential for revitalising their businesses.

\section{METHODS AND LOCALITY CASE STUDY}

The case study was the cluster of tourism enterprises centred upon the Overstrand Local Municipality in South Africa's Western Cape province. The municipality ranks as the fourth most tourism-dependent in the country with Hermanus its largest town. Within the Overstand cluster are several tourism destinations such as Kleinmond, Betty's Bay, Stanford, Elgin, Bot River and Gansbaai as well as Hermanus. The area encompasses a range of tourism niches. First, is coastal and marine tourism, specifically whale watching, nature cruises, scuba diving, kayaking and beach tourism (McKay, 2020). Second is adventure tourism which intersects with some coastal tourism activities but also includes zip lining canopy tours, hiking and rock climbing, quad biking, hang gliding and kite surfing (Rogerson and Rogerson, 2019).

The scenically beautiful and hilly interior is the locale of some of South Africa's premier wineries such as around Elgin, Bot River, the Hemel-en-Aarde Valley and Stanford. These wineries and small touristic towns are home to many premier restaurants and mainly organically grown produce (olives, cheese, cider, apples, pears) which has resulted in the Overstrand being awarded in 2019 the status of Africa's first UNESCO Creative City of Gastronomy (Rogerson and Rogerson, 2021b). Overall, the cluster exhibits a strong tourism economy which is heavily leisure-based and with critical reliance on international tourists for tourism spend and support of the commercial accommodation services. 
In interrogating tourism business responses to the impacts of the COVID-19 pandemic a qualitative approach was adopted with semi-structured interviews undertaken with a cross-section of key private sector tourism product owners. The interview schedule was designed to determine issues of COVID-19 responses of enterprises and challenges, the role of government regulation and future business prospects. Interview material was analysed through content thematic analysis. A content analysis approach was employed to interrogate the transcribed qualitative interview data. The thematic approach applied followed the approach as suggested by Braun and Clarke (2006). In total 20 interviews were completed during the period

Table 1. The Overstrand cluster of interviewed entrepreneurs

\begin{tabular}{|c|l|c|l|}
\hline Identifier & \multicolumn{1}{|c|}{ Type of Business } & $\begin{array}{c}\text { Years in } \\
\text { Operation }\end{array}$ & Number of Employees \\
\hline O1 & Country Market & 2,5 & 85 \\
\hline O2 & Zip Lining (canopy tours) & 6 & 35 \\
\hline O3 & Diving and Boat Cruises & 9 & 5 and 2 part time (now 1 part time) \\
\hline O4 & Wine Estate & 10 & 40 \\
\hline O5 & Wine Estate & 20 & 32 \\
\hline O6 & Wine Estate & 40 & 30 \\
\hline O7 & Craft Brewery & 9 & 2 and 8 part time \\
\hline O8 & Tours and Transfers & 10 & 2 (was 5) \\
\hline O9 & Restaurant & 17 & 5 \\
\hline O10 & Restaurant & 11 & 12 \\
\hline O11 & Five star eco-lodge & 24 & 100 \\
\hline O12 & Four star guest house & 17 & 5 \\
\hline O13 & Four star guest house & 16 & 9 (was 15) \\
\hline O14 & Three star guest house & 21 & 3 \\
\hline O15 & Self-catering house & 12 & 2 \\
\hline O16 & Self-catering apartments & 10 & 4 \\
\hline O17 & Bed and breakfast & 8 & 2 \\
\hline O18 & Bed and breakfast & 10 & 3 \\
\hline O19 & Farm cottages & 17 & 2 \\
\hline O20 & Backpackers & 21 & 2 (was 5) \\
\hline
\end{tabular}

December-2020 to February 2021. Of these

interviews 75 percent were in-person face-to-face meetings conducted with due regard to appropriate social distancing; the remainder were telephonic interviews. The list of tourism business interviews is shown on Table 1. It is evident that a broad range of tourism enterprises was interviewed in order to cast the net wide and gain a variety of inputs. The mix of interviews encompassed variously the organiser of a country market, adventure tourism operators (2), wine estates (3), a craft brewery (1), tours and transfers (1), restaurants (2) and the full gamut of accommodation providers from high end five-star accommodation to four and three-star guest houses, bed and breakfasts, farm stays and backpackers (10). Fifteen of the tourism enterprises who were interviewed had been in business for ten years or more. As established businesses they are embedded into not only the tourism economy but the broader local economy due to supply chains. Four other tourism businesses had been in operation for between six to nine years with only one business operating for less than five years. Seven of the tourism businesses employed thirty or more people.

The largest enterprises were an award winning five-star lodge employing 100 staff, a country market which employs 85 and an adventure tourism establishment as well as the three wineries each employing between 30 and 40 staff. The rest of the businesses which comprise an adventure tourism outlet, tour operator, craft brewery and a variety of accommodation providers each employ between two and nine people. It should be noted, however, that these employment numbers were those current at the time of the interview and in many cases these businesses employed more staff prior to the onset of COVID-19 (Table 1). The following sections unpack the impacts of the COVID-19 pandemic on local tourism businesses, supply-side adaptation or response strategies, business challenges, the role of government and business prospects. The analysis draws on the words and feelings on the interviewees and every effort has been made to reflect the voices of the area's tourism entrepreneurs and business managers.

\section{Business responses to changes in demand}

The COVID-19 pandemic has affected all of the tourism establishments in Overstrand and its surrounds, negatively. Words and phrases used to describe the impact that this has had on their business include: "devastating" "less of everything", "survival is the bottom line", "eye opening", "unless BEE compliant can't survive", "change", "unpredictable", "it's been crippling", "totally decimated", "destroyed the South African market", "disastrous for the most part of 2020", "horrific", and "quite painful but not devastating". A major part of explanation for the highly negative impacts relates to the strong orientation of tourism businesses in the research area towards international tourism. In the Overstrand cluster this is especially the case for the hospitality and accommodation sectors. The 5 star eco-lodge, adventure diving and cruise boat establishment are the tourism products most reliant on foreign tourists. For other tourism products, such as the country market, the craft brewery, zip lining (canopy tours) and a few wineries, there was evidence of a majority domestic market or even split between international and domestic tourists. All businesses experienced a change in demand since the onset of COVID-19 and the collapse of international tourism. In a number of cases hope was expressed that demand for tourism products would increase from domestic tourists. In many cases, however, this has not occurred as a consequence of the wider impacts of COVID-19 on the South African economy and correspondingly of reduced discretionary expenditure. Of significance also is that certain respondents identified "the fear" factor of travel as another factor in accounting for laggard domestic demand. In addition, the interviews were conducted at a time when national government imposed a harsh lockdown that included a ban on sale of alcohol as well as closure of beaches/swimming pools and early evening curfew. These issues are highlighted in interview responses as follows:

Don't really see many changes as people don't have money. We have dropped rates to encourage domestic tourists - R3 800 for sea facing room is now R2 600/2 200. Hoping to see some sort of pick up in March and Easter (O13).

Less demand as most domestic guests are affected financially, so weekends away are now considered a luxury. And the threat of COVID making potential domestic guests wary of communal facilities and interacting with strangers (O20). 
A lot of people are not going out as they are in fear (O7).

The South African economy has shrunk and the economic onslaught continues. Domestic tourists have less disposable income to spend on leisure and this impacts demand (O11).

Possibly more local tourists looking to escape the city but this is not showing yet (O19).

Some businesses recorded a marginal increase in domestic tourists which assisted in keeping their businesses open at a survival level. This said, in this part of South Africa the spending from domestic tourism cannot replace the reliance upon higher-spending international tourists.

We have increased percentage of domestic visitors over the past few years and expect more local visitors going forward (O12).

Marginal change from domestic tourism. National (from different provinces) seems to have dropped. Business down more than 50\%. Not seen a big uptick in domestic demand. Not able or willing to devalue our product. Margins are already narrow as the beach ban dissuaded upcountry people from visiting or staying longer $(\mathrm{O} 2)$.

Yes, we expect more domestic visitors as South Africans can't travel abroad (O13).

We were pleasantly surprised. Domestic tourism rapidly increased mainly from December but throughout last year. Local tourism kept the business afloat although no replacement for the international tourists. South Africans friendly, supportive and eager to tip, sometimes $100 \%$ tip after a dive trip R1000 (O3).

The tourism enterprises have undertaken a number of responses to address the changing demand as a result of no international tourists and cautious domestic tourists many of whom are fearful of catching the virus or under financial strain. All establishments have visibly implemented full legislated safety protocols for COVID-19. Another common denominator across all tourism categories is a dramatic increase in their online/social media presence as businesses sought innovative ways to market themselves to the domestic market. The energetic and innovative responses of the organizer of the country market are worthy of note.

Before Christmas through the local tourism committees it was clear that Cape Town and the Overberg were attracting large number of Gauteng tourists. I took out simultaneous radio adverts in Johannesburg and Cape Town. The ads played on Magic 828 for Cape Town and on 702 for Johannesburg. The message was reinforced as Joburgers heard the same message when they travelled to the Cape on holiday. Astounding results with over $30 \%$ of cars in the carpark with GP plates. More than they have ever had since opening two and a half years ago. Radio stations also losing revenue so for a few 1000 Rand extra they incentivised us to spend a bit more and the ad reach grew by 150000 . In these times it is important to be pro-active, innovative and get out there. To attract the people from markets that have closed like Hout Bay Route 44, Lourensford I was also on local radio stations such as WhaleCoast FM to attract Hermanus visitors (O1).

Further, in common with trends observed in other parts of South Africa, price-cutting was a supply-side response to the crisis for nearly all of the tourism enterprises. Businesses had to lower or freeze their rates to entice domestic tourists in order to ensure that their offerings were desirable and affordable. These specials and rate cuts have been advertised extensively on social media and through online tourist booking platforms. The voices of the accommodation establishment operators illustrate these trends.

We are currently running a digital campaign - Summer Sun special which will run through to the end of April and we ran a Spring Splendour special (O11).

During November level 2 and 3 had a special on the eco tours but to compensate have not increased prices to keep business afloat $(\mathrm{O} 3)$.

We can't vary our product offerings, but we have trimmed some of the added extras that we used to offer in an effort to reduce costs. We've also offered specials aimed at local families $(\mathrm{O} 2)$.

Price reductions being offered via booking sites $(\mathrm{O} 20)$.

Specials for mid-week stays, stay for 3 and pay for 2. Contactless check in. Sanitizing deeply in between stays (O19).

Responded by decreasing rates. More focused on the local market. Always had a 'local is lekkker' rate drop of 20\% now it is $30 \%$ and previously was mainly applied in the low season when internationals were not around. There is business over the week-ends but during the week very quiet with discounts up to $45 \%$ and still many days there are no guests. Hopeful that it will pick up (O13).

Another strategy that tourism enterprises used to adjust their existing offerings towards domestic tourists was to introduce more diversified and often family-friendly products which they advertised to the local market. For the Overstrand cluster, alongside the various lockdowns, the banning of alcohol sales was particularly damaging to the tourism and hospitality sectors which has a substantial element of food and wine tourism. In response those businesses engaged in alcohol production developed a range of more family friendly activities to encourage visitors to their establishments. Examples are that wineries allowed pets and introduced children's activities and the craft brewery sold more novel soft drinks and other wineries conducted on line tastings.

As a wine estate we have diversified our product offerings to be more family friendly and less wine - oriented. Welcomed pets on leads. Introduced or ramped up more family focused activities such as - children's waterpark, jungle gym, picnics, boat rides. Putt Putt with a family friendly restaurant attached (O4).

We had to find things to sell that we didn't normally sell. Different to coke such as rock shandy. There is a market for soft drinks due to regulations on drinking and driving $(\mathrm{O} 7)$.

People are not keen to go out and taste wines so they do online tastings with trade and customers and groups of wine enthusiasts This generally has worked well - chatting to the wine maker especially for international buyers so they get a feel 
for the farm. Sometimes winemaker chats from the vineyards which gives people the feeling that they are there - will carry this on with internationals after COVID. Using WhatsApp and Zoom in the vineyard and for tastings with foreign buyers has been a positive spin off from the pandemic (O5)

Finally, it was highlighted by one interviewee that in the current negative policy environment that faces tourism businesses in South Africa that "tourism operators are going offshore to Mauritius or Europe but keeping operations in South Africa". (O2) The explanation was given that this move was more tax effective and what was driving this move was uncertainties about directions of national tourism policy. The interviewee added "We are looking at this option as well" (O2).

Overall, the responses from businesses emphasized strategies of self-reliance with accompanying shifts in revenuegeneration and reduction in work-hours . For other businesses - most notably the adventure tour operations massively reliant on international travellers, the response can be characterised as of vigilance as their situation precluded them from controlling their destiny and thus their options are either to undertake preparations for a new post-pandemic regime or to become inoperative, discontinue operations, or standby for new protocols permitting a reopening of business.

\section{Business Challenges}

The major challenge for all business owners was to keep the business open and to survive financially. With minimal support provided by national government necessarily the enterprises had to be self-reliant in their responses and address a range of challenges. In particular during the December and January holiday period (2020-2021) the alcohol and beach ban put added strain on already struggling tourism businesses in the Overstrand and environs to avoid closure of their operations.

Challenge is more feet through the door and the uncertain future which is unpleasant. Trying to keep tenants, giving rent reductions and anything to keep up some sort of cash flow. It is a nightmare. With me and the tenants there is a feeling that we are all in this together and all trying to do whatever it takes to survive (O1).

The major challenge is keeping the business open. Keeping afloat is difficult and I contemplate closing the business three times a day (O8).

Staffing was an important issue for most cluster respondents. Some businesses could not afford to keep all their staff and reluctantly had to reduce staff numbers. Other cost reducing measures that were implemented included mothballing part of their accommodation establishment, turning off geysers, DSTV and fridges. In an effort not to retrench many businesses cut staff salaries and work hours in half. These points are elaborated by accommodation respondents as follows:

Reduction in staff, no upgrades to the rooms and very basic services so that you don't have too many costs (O12).

The challenge is that the business imperative is simply survival. There is no room for the introduction of innovative new products. The business survival is critical to the staff and also the community work the business drives through its Foundation (O11).

We've also made a monumental effort to reduce the monthly overheads of running the business, such as cancelling our security contract, reducing insurance to minimums, turning off geysers and fridges in our adjacent building when not in use. And sadly, reducing wages - we previously employed four cleaning staff, one front of house, a gardener/handyman and two or three international volunteers, now we have one cleaner, one front of house $(\mathrm{O} 20)$.

For the crippled local adventure tourism sector, unable to afford to keep critical trained staff was of major concern. The operator of a major ziplining operation articulated the following:

Retaining highly trained staff is our main concern. We've started reducing our operating days, but we don't want to close, because that produces a negative public image, and there is a lag in start-up again. But we can't continue to make a drastic loss through the coming low season. Most staff been with us since the beginning. Not feasible to re-train people they are all local community members (from Grabouw) (O2).

A further challenge to the accommodation and hospitality sectors given the dearth of international tourists and slump in domestic demand was the necessary flexibility to deal with late bookings and cancellations.

Challenges are the last minute bookings and cancellations. The major challenge is to keep up standards even though rates are lower and to keep afloat until the end of the pandemic Major challenge is that lower prices affect our bottom line. We are in the self-catering niche which is surviving better than other types of accommodation. Fairly quiet during the week but full most week-ends. Last week no bookings by Tuesday but by Friday were full. This is the last minute new normal. No preplanning anymore we have to be on the ball all of the time. Apartments need to be ready to go all of the time. Internationals would book well in advance so more notice period (O16).

Despite the many negative consequences of the COVID-19 pandemic and the various lockdown regulations and the threat to all of the businesses livelihoods, several interviewees saw potential opportunities. The following interviewee responses speak loudly to the resilience of local tourism businesses and their self-reliance in the context of the pandemic.

Always opportunities. This disaster has made us think out of the box (O1).

It is great that there is an enthusiasm for exploring what is on offer domestically. So the market that normally would travel overseas each year is happy to support a local tourism product. The lockdown restrictions have tempered this enthusiasm. Also taking this time to get the basics right. Usually tourism is driven and high paced so this slow down means there is time to engage extensively with their sustainability principles such as waste management and environmental management. We focus on doing better things that have no cost. It is also very important for management to keep staff motivated and involved as issues around mental health are important $(\mathrm{O} 11)$. 
The opportunity was to utilize technology better to keep in touch with visitors and clients and to stay close to people (O5).

Outdoor activities are big in the Cape. We plan to focus on this market by offering mountain biking trails and hiking. Customers are looking for outdoor experiences so our space on the farm is a good opportunity to catch those looking for something to do while being able to be outdoors in the fresh air (O6).

Opportunities are maybe working with other businesses We are teaming up with 10 other Hermanus businesses and advertising in a Cape Town magazine that advertises widely. The main aim is to market Hermanus as if we can get visitors to visit the town then we all win so the first goal is to market the place and then specific offerings. Focus on local more and run more specials $(\mathrm{O} 13)$.

All interviewed tourism enterprises sought either to introduce new products or alternatively to adjust existing offerings in order increase their attractiveness to domestic tourists and thereby improve their enterprise bottom line. Keeping prices affordable for domestic tourists and focusing on marketing and improved social media presence were strategies deployed by most tourism enterprises. In addition, some modified or added to their existing offerings. Restaurants have, in many cases, simplified their menus and others have added frozen meals to their businesses. At two winery restaurants frozen meals can be purchased at the premises and one of the wineries went even further by instituting a delivery service to deliver meals as far as Cape Town, 100km away. A major benefit of this enterprise diversification was that they were classed as 'essential workers' and thus were able to grow this part of the business during the first hard lockdown. Subsequent to the hard lockdown the business continued to grow such that they have had to employ more cooks (O6).

The frozen meals are new products from our restaurant. In the winery we are scaling back on the wines and focusing on styles within specific wine series and ranges. The winemaker has been experimenting and they have now gone back to storing white wines in clay pots. Their philosophy is to keep things fresh and different. They looked at their offerings and decided to pare down their wines and organize them differently (O5).

At the one surviving country market the strategy and business opportunities were explained as follows:

Focus on marketing. We do what we have to do. Revamping the shops and constantly improving the offering and adding new touches all the time. Repeat visitors need to see something new so it is important to stay fresh and relevant. Look at small innovations. After the popularity of Queens Gambit on Netflix we brought in three chess boards. People linger and play parents teach their children. People enjoy them and over the 3 months not one piece has gone missing and taken. It is $100 \%$ a mindset. It is easier to give up rather than fight -"the barbarians are at the gate" mentality. Some businesses have failed but mainly due to defeatist attitude, easier to throw it all in. Also we encourage the traders to try new offerings. One food seller always had some of his lamb left over. We chatted and he decided to make pies which can be frozen and taken away as well which added a new little side line to his business $(\mathrm{O} 1)$.

For the owners of a backpacker lodge with the collapse of the international market the business had to pivot towards accommodating particular groups of short-term visitors.

We've directed more energy into adapting the business to cater to building contractors coming to the area, long term guests such as Telkom engineers, doctors on assignment at the local hospital and building contractors (O20).

Other different opportunities were explored and activated as tourism products by the sample's resilient entrepreneurs as self-reliance interventions for new opportunities. The different opportunity pathways are highlighted in the following responses.

We need to do more than just give each other referrals but create a platform and package things. We are looking to put a poster together or video at Cape Town Airport international arrivals with names of each of their businesses (O2).

Used lockdown to launch a new website and to sharpen our social media and newsletter presence. Opened a deli on the farm to increase wine sales through this. Just completed our 10km Mountain Bike trail which we will launch in March. Plan to improve hiking trails. We focus on producing more fruit rather than grapes because of the alcohol bans (O6).

Looking to convert an old building to increase our accommodation to 3 cottages. Possibly the building of a yoga deck to accommodate retreats on the farm $(\mathrm{O} 19)$.

No new offerings just new pricing and ability to keep a credit for 12 months instead of cancelling and freezing the rate. No rate hikes until 2022 (O13).

Seven of the Overstrand cluster of tourism businesses downsized their business to some extent. Restaurants by law can only seat a certain number of people due to social distancing legislation so are automatically smaller than in pre-COVID times unless they have managed to accommodate those diners in suitable outdoor locations. Several accommodation providers have also downsized by shutting up/ mothballing/decommissioning some of their rooms, outbuildings or in one case a whole lodge in order to save money on staff and overheads. Other businesses have cut down on their products or their services, however, they all recognize that closing is not an option. These are signals of vigilant entrepreneurs waiting for post-pandemic revival.

Only one of the two lodges are open. Villas open on an ad hoc basis (O11).

Downsizing. Started this prior to COVID. Owning less cars and just trying to stay afloat. Not at the point where I will say no to business. I have diversified into some non-tourism business (O8).

Reduced quantity of beer that we produce. Economizing as to how they purchase supplies. Have not reduced prices but continued as before. Not looking at any change. It is not the time (O7).

Yes. Fewer tours a week and cutting down on overheads. Can't afford to close as then more difficult to open up after long lag period $(\mathrm{O} 2)$. 
Sort of downsized as now they only run the main building with 11 rooms and outside buildings have turned off fridges, geysers and cancelled DSTV. Even though they have downsized still had to run 2 breakfast shifts to keep physical distancing rules (O13).

Despite the difficult trading conditions many of the cluster's tourism businesses were not willing to downsize or reduce their business despite the current hollowing out of the tourism industry as a whole in South Africa. The respective responses of the operator of the country market and one restauranteur are revealing:

No! Downsizing is the worst thing that you could do. Would like more business and more visitors but will not downsize. I went and visited other markets in Cape Town and many were closed or barely functioning, others have closed down. I see that as opportunity and have used radio ads and social media to keep awareness of Elgin market high and encourage visitors (O1).

No we have stayed open 7 days a week despite many week days being extremely quiet (O10).

Finally, inter-enterprise cooperation with other local cluster businesses remained an essential business response. In total it was disclosed that 19 of the 20 interviewees co-operate with other businesses. This co-operation occurs variously in the form of joint marketing, information sharing or referrals. In addition to co-operating in order to assist other businesses many recognize that it is important to all come together to sell the destination first and encourage tourists to the area rather than merely focusing on one tourism business at a time as increased visitor's benefits all businesses in the area.

We co-operate within the group and do more joint marketing with a range of Hermanus businesses to encourage visitors to visit the town (O12).

We work in a tight community so there is information sharing and dialogue across the industry and community (O11).

Absolutely. The dive charters supports other tour packages and they get permission. So there is a reciprocity with other adventure tourism businesses as well as waiters at restaurants - if they sell dives waiters get commission. Word of mouth is incredibly powerful. All adventure tourism needs to do well to attract tourism to Hermanus as we need lots of tourism businesses otherwise nothing to attract tourists (O3).

We co-operate within the group and do more joint marketing with a range of Hermanus businesses to encourage visitors to visit the town (O15).

Always referred to other accommodation suppliers and recommended places to eat and visit. Need more formal linkages through joint advertising for Hermanus as a whole and individual businesses as well (O13).

\section{The role of government and future business prospects}

Interviewees were asked a number of questions relating to the role of government. First, if government regulations during the pandemic affected their business positively or negatively. Second, what local government and national government could do to assist and which of these interventions would assist in responding to the challenges of supplying the domestic tourist market in the short term (next 12 months). In terms of the impact of government regulations it should be noted that some of the interviews took place during the alcohol and beach ban which was in place from December into February and consequently most of those interviewees focused on those restrictions which was a further challenge to their business during these already business-stressed times. Most negative comments related to government regulations focused on the alcohol and beach bans as well as the curfew especially for the restaurant businesses which particularly impacted those in the night time tourism economy. The interview responses highlighted contradictions in alcohol policy as well as the devastation caused to coastal tourism businesses by the December beach ban. The views of several respondents below reveal the debilitating consequences of government regulations for the Overstrand tourism business cluster.

Negative effects and $100 \%$ of that is due to the liquor restrictions. The clientele who visit the market are responsible. 320 000 people through these doors and only 2 drunkards Are the government rules penalizing the responsible for the tiny proportion of irresponsible? Not one car crash as the traffic police are always around and would have notified of anything. Curfew has impacted the dinner trade at night, barely worth-while and only just breaking even but will continue as it is a social outing for the locals and can't afford to lose tenants who also need all the business that they can get. There is also nobody to replace tenants as in normal times as nobody has any start-up capital or funds to start another business (O1).

When the new regulations came into force on 27 December the whole area 'packed up and left'. No beaches, the curfew and alcohol ban destroyed the idea of a holiday and they as well as surrounding tourism businesses had many cancellations (O11).

Affected negatively due to loss of business. On the 27 December we had total cancellations of diving and cruises. We could not operate sunset cruises due to curfew and not allowed to sell liquor. We make $40 \%$ of annual revenue during the December/January period so this was devastating. The December months subsidize the 3month lull in the winter months (June to August) (O3).

The curfew had a negative effect on planned events - New Years' Eve party, outdoor cinema evenings, afternoon music events. The drinks ban put visitors off visiting the restaurant. Very busy with domestic tourists visiting up until 27 December then many visitors left the Hermanus area especially with the beaches being closed as well (O4).

Government regulations affected us negatively. We operate out in the open, in a nature reserve. Having Cape Nature as landlords, we were not allowed to open particularly because ziplining was not specifically allowed (O2).

Very negatively. Understandably, the closure of our international borders to stop the spread but interestingly the closure of beaches and the alcohol ban of late December 2020 was more of a blow as this was our peak season and an opportunity to make a little money. We had so many late cancellations that the peak dates over New Year saw empty rooms, where previous years we'd had waiting lists - traditionally the Christmas/New Year dates are almost entirely domestic tourism (O20).

Only negative impacts. When beach ban came in we had a lot of cancellations. We are across the road from the sea. 
Earlier in December it was not looking too bad and we had visitors that were booking for longer than usual - a week or longer as these were people who normally went overseas so had money to spend on a local holiday. We were full for part of December but the beach ban meant cancellations and lower occupancy (O13).

In addition to the lockdown regulations which disincentivized travellers, the government announcements to stay home or within bubbles fostered a fear of travel and of mixing with others which further affected tourism businesses negatively. As was expressed by a local tour operator: "COVID has created a lot of uncertainty and people more cautious to travel freely" (O8).

It should be noted that in one case the business did not see the government regulations as only negative. This winery was able to increase overseas wine sales which subsidized the shrinking of their restaurant and tasting room business. It was also seen as a time to train staff and increase their online presence. The enterprise response of this wine estate operation is a further indicator of resilience in the cluster of operational tourism enterprises.

It was very difficult at first but overall the positives outweigh the negatives. Early April 2020 the owner met with all employees and set targets which they had to meet otherwise there would be cuts. The following month the hashtag \#savesouthafrican wine went viral. Our larger overseas markets continued to import our wines. Consequently, not one staff member was lost which means that negative knock-ons to the broader community was low. The private online market was also amazing. Three years ago their online shop made around R60 000 and last year the increase was exponential. Buyers have shifted en masse to online. Initially, logistics companies were inundated and there were early problems with couriers. They did adapt. For us the major negative was lower numbers in the restaurant due to the restrictions. During lockdown staff who deal with the public were also demotivated as there were fewer people around. They did not lose their jobs so not such a big negative. The lockdown did free up some time which normally they would not have so training was ramped up which benefited a number of staff members (O5).

The major positive national government policy intervention which assisted a number of the cluster's tourism establishments was the Temporary Employer/Employee Relief Scheme (TERS) payments to staff who qualified as in many cases that minimized retrenchments and augmented the salaries of those workers who are on the bottom rung of the tourism employment ladder such as housekeepers, cleaners and gardeners.

Most interviewees hoped that local government might assist them by reducing business rates during the difficult times, albeit acknowledged that this was unlikely to happen. For example, the operator of the country market stated that it "Would be great if they could reduce the rates and taxes but that will not happen. Elgin and Grabouw council has no marketing budget so they cannot even help with awareness and encourage visitors to the town" $(\mathrm{O} 1)$. Another major theme that flowed through the interviews was for the local government to be more pro-active in advertising the locality.

To stop promoting Hermanus as a 'whale only" destination as that season is only for 5 months but Hermanus has a range of products - diving, hiking, art galleries, wine. As Hermanus mainly promotes whales it could get more tourists by advertising itself more widely than whales. Need to diversify, particularly for ocean tourism (O3).

Bot River is not really on the wine map so local government could increase marketing of smaller wine regions. We have had to make ourselves a destination but Bot River needs more work. Each farm is fairly insular need to think how to benefit all (O6).

Other respondents recognized that local government was struggling to provide their basic mandate and did not have the finances to market the tourism products in their area. In at least one case - that of a large ecolodge - enterprises pro-actively went out of their way to assist their local municipality to feed people who had lost jobs and could not fend for themselves.

Have had a close working relationship with local government for many years. They are trying their best but not able to cope. Most people in the area employed in tourism as fishing industry no longer viable. Municipality helped with the feeding scheme early on but could not afford to sustain it. They struggle to do the basics. We have stepped in to help and all of the lodge staff help to prepare or distribute food to the local people who are struggling and we have provided over 300000 meals. We feed 650 people per day and try to focus on the children. We also provide a two-week survival kit for those who have to self-isolate due to COVID-19(011).

The support needs that the cluster of tourism enterprises required from government are varied and included the request to extend TERS, improve public transport, encourage a local culture of travel and to enhance the marketing and promotion of South Africa. Further, in the case of the wine tourism sector there was a request for more nuanced appreciation by government of the operations of alcohol producers. This was expressed in the statement in the case of wineries for government to understand that they are "wine farms and not liquor outlets" (O4).

A key finding across the Overstrand cluster is that government actions relating to the alcohol bans and beach closures have resulted in a disconnect and reduced levels of trust and between the tourism industry entrepreneurs and government. Inadequate communication and sharing of information with the private sector were flagged as key issues. The operator of the country market stated as follows:

Generally, we ignore government. We understood the need for a curfew and social distancing but banning alcohol made no sense. We don't understand how or why these decisions are made and have lost faith with government. They do not share information which is then passed from province downwards and decisions are arbitrary and makes people believe that there is no rational basis for decision in the first place...... National government should improve public transport so that staff and visitors can get around. Nothing has really come through from national government encouraging domestic travel or a culture of travel (O1). 
The core support interventions as expressed by respondents in the Overstrand cluster are evidenced from the following responses:

National government could support tourism staff and not leave it all to the owners. TERS at the same level as before would be great. (011).

We understand the need for tourism businesses to be run by all South Africans and we are all passionate ambassadors for South Africa. It seems that other African countries tourism industries have not been as damaged as South Africa. Kenya is doing $O K$ and they have made it clear that they are open for business. A few months ago they flew in American agents - they are proactive and seeing results. We are becoming a pariah $(\mathrm{O} 11)$.

National Government could encourage a culture of travel. Sell South Africa better to all South Africans - advertise and enhance what this country has to offer (O8).

Important short-term interventions that were put forward by the tourism enterprises in many cases overlapped with what many had said with regard to support from national government. Again, improved marketing of South Africa and its various touristic regions was a recurring theme. This is illustrated in the view expressed by a local tour operator: "The most important intervention would be to sell and promote South Africa to local tourists. Let places create good experiences so that visitors return" (O8). Overall, the need to open up the beaches and unban alcohol was echoed by many who were interviewed during the lockdown period. In addition, more education of the general populous explaining that they are safe if safety protocols are followed by tourism businesses was also a plea from a number of interviewees.

Intervention that would assist is for people to be educated more about the pandemic. There is such a fear of the unknown that people are scared to go out. Tourism spaces have prepared and introduced safety protocols and if people wear masks and sanitize they should go out and enjoy themselves sensibly. Equip people with knowledge but encourage them to travel (O5).

All of the Overstrand cluster interviewees were optimistic that they would still be operational by 2022. This said, whilst none of them forecast permanent closure, a few suggested that they would drastically cut back or close down for part of the winter months, a traditional downturn business period when there is more reliance on the domestic market.

In 2020, however, these businesses did not enjoy the financial boost from a healthy Christmas season with international tourism to tide them over the quieter times. Some of them were resolute others were more negative albeit remaining upbeat despite the current COVID environment.

The rest of this year will be a slow uptick which is a long and slow process. We are here for the long-haul (O1).

No matter how many or few guests be welcoming and do the hospitality job to the best of your ability. It is a head-game to keep motivated. We need each other there is still great value in getting up and going to work and meeting colleagues. We are looking to survive but not sure what shape or form we will be in 12 months' time. It is purely survival at the moment and we are all in the same boat with other tourism enterprises - restaurants b and bs etc (O11).

Stay open. Be innovative and hope that lifting of alcohol ban and beach ban and extended curfew will encourage more visitors (O4).

In 12 months' time probably in the same position. Hoping that I will still be afloat. That is all no further expectations (O8).

Fortunately, we own the buildings we operate from and have reduced staff and overheads to the point where we hope that although not profitable, the business will be able to at least make a reasonable contribution to its overheads. We the owners, are contributing to the running costs of the business from our savings and a cashed in pension policy. If we're still here by early 2022, when we hope to see some recovery in tourism, we'll be broke and nervous. We have considered closing the business and selling the buildings - but this is also not a great time for that option either (O20).

We will continue to focus on the local market and keep a strict eye on expenses. After 6 months we will need to look at staffing again. We did not retrench but not sure how we can keep going with current staff levels if no government support (O12).

Overall, these statements attest to the self-reliant character of businesses in the study area and the vigilance of others in seeking to prepare for opportunities in a post-pandemic environment.

\section{CONCLUSION}

The COVID-19 pandemic has created major uncertainties by radically recasting the landscape for the owners and operators of tourism businesses. In the expanding scholarship on COVID-19 an important topic is that of supply-side responses to the changes taking place in consumer demands, the resilience of local tourism enterprises and coping strategies. This locality case study in South Africa points to the self-reliant character of the community of tourism enterprises in and around Overstrand in the Western Cape in addressing the challenges of a deteriorating business environment. Product diversification, reductions of prices, reduced staffing, changed marketing, greater inter-enterprise cooperation are several of the most significant business adjustments revealed by the Overstrand cluster. With the negative financial impacts of COVID-19 on local tourism enterprises exacerbated by government measures for alcohol bans and beach closures there is evidence of a disconnect and lack of trust between the area's local businesses and national government. This suggests that as part of the range of initiatives which are required for successful tourism recovery planning in South Africa the rebuilding trust between government and the established private sector tourism businesses will be another critical issue.

\section{Acknowledgements}

Thanks are due to South Africa's Department of Tourism for funding this research. Robbie, Dawn and Skye Norfolk assisted with inputs to the paper. 


\section{REFERENCES}

Alonso, A.D., Kok, S.K., Bressan, A., O’Shea, M., Sakellarios, N., Koresis, A., Solis, M.A.B., \& Santoni, L.J. (2021a). COVID-19, aftermath, impacts, and hospitality firms: An international perspective. International Journal of Hospitality Management, 91, 1026554, https://doi.org/10.1016/j.ijhm.2020.102654

Alonso, A.D., Bressan, A., Kok, S.K., Sakellarios, N., Koresis, A., O’Shea, M., Solis, M.A.B., \& Santoni, L.J. (2021b). Facing and responding to the COVID-19 threat-an empirical examination of MSMEs. European Business Review, https://doi.org/10.1108/EBR-09-2020-0231

Assaf, A., \& Scuderi, R. (2020). COVID-19 and the recovery of the tourism industry. Tourism Economics, 26 (5), 731-733.

Bartik, A., Bertrand, M., Cullen, Z., Glaeser, E., Luca, M., \& Stanton, C. (2020). How are small businesses adjusting to COVID-19? Early evidence from a survey. XXXX: National Bureau of Economic Research Working Paper, 26989.

Bhaskara, G.I., \& Filimonau, V. (2021). The COVID-19 pandemic and organisational learning for disaster planning and management: A perspective of tourism businesses from a destination prone to consecutive disasters. Journal of Hospitality and Tourism Management, 46, 364-375.

Braun, V., \& Clarke, V. (2006). Using thematic analysis in psychology. Qualitative Research in Psychology, 3 (2), 77-101.

Bressan, A., Duarte Alonso, A., \& Kok, S.K. (2021). Confronting the unprecedented: micro and small businesses in the age of COVID19. International Journal of Entrepreneurial Behavior \& Research, 27 (3), 799-820.

Brouder, P. (2020). Reset redux: Possible evolutionary pathways towards the transformation of tourism in a COVID-19 world. Tourism Geographies, 22 (3), 484-490.

Carr, A. (2020). AOTEAROA: A post-COVID nature-centric world. ATLAS Tourism and Leisure Review, 2020-2, 30-36.

Deb, S.K., \& Nafi, S.M. (2020). Impact of COVID-19 pandemic on tourism: Recovery proposal for future tourism. GeoJournal of Tourism and Geosites, 33 (4), Supplement, 1486-1492. https://doi.org/10.30892/gtg.334sp106-597

Dias, A., Patuleia, M., Silva, R., Estêvão, J., \& González-Rodríguez, M. (2021a). Post-pandemic recovery strategies: Revitalizing lifestyle entrepreneurship. Journal of Policy Research in Tourism, Leisure and Events. https://doi.org/10.1080/19407963.2021.1892124

Dias, A., Silva, R., Patuleia, M., Estêvão, J., \& González-Rodríguez, M. (2021b). Selecting lifestyle entrepreneurship recovery strategies: A response to the COVID-19 pandemic. Tourism and Hospitality Research.

Godovykh, M., Pizam A., \& Bahja, F. (2021). Antecedents and outcomes of health risk perceptions in tourism, following the COVID-19 pandemic. Tourism Review. https://doi.org/10.1108/TR-06-2020-0257

Gössling, S., Scott, D., \& Hall, C.M. (2021). Pandemics, tourism and global change: A rapid assessment of COVID-19. Journal of Sustainable Tourism, 29 (1), 1-20.

Hall, C.M., Scott, D., \& Gössling, S. (2020). Pandemics, transformations and tourism: Be careful what you wish for. Tourism Geographies, 22 (3), 577-598.

Higgins-Desbiolles, F. (2020). Socialising tourism for social and ecological justice after COVID-19. Tourism Geographies, 22 (3), 610- 620.

Jiang, Y., Ritchie, B.W., \& Verreynne, M.L. (2019). Building tourism organizational resilience to crises and disasters: A dynamic capabilities view. International Journal of Tourism Research, 21 (6), 882-900.

Kock, F., Nørfelt, A., Josiassen, A., Assaf, A.G., \& Tsionas, M.G. (2020). Understanding the COVID-19 psyche: The evolutionary tourism paradigm. Annals of Tourism Reearch, 85, 103053.

Korinth, B. (2020). The impact of COVID-19 on foreign travel plans of Polish tourists, 2020. Studia Periegetica, 32 (4), 59-69.

Kowalska, K., \& Niezgoda, A. (2020). COVID-19 as a tourist activity inhibitor as evidenced by Poles' holiday plans. Studia Periegetica, 32 (4), 9-24.

Kvirkvelia, N., \& Tsitsagi, M. (2021). Impact of COVID-19 on tourism in Georgia - An overview. Georgian Geographical Journal, 1 (1), $27-33$.

Li, Z., Zhang, X., Yang, K., Singer, R., \& Cui, R. (2021). Urban and rural tourism under COVID-19 in China: Research on the recovery measures and tourism development. Tourism Review. https://doi.org/10.1108/TR-06-2020-0357

McKay, T. (2020). Locating great white shark tourism in Gansbaai, South Africa within the global shark tourism economy. In J.M. Rogerson, G. Visser. New Directions in South African Tourism Geographies, Cham, Switzerland: Springer, 283-298.

Neuburger, L., \& Egger, R. (2020). Travel risk perception and travel behaviour during the COVID-19 pandemic 2020: A case study of the DACH region. Current Issues in Tourism https://doi.org/10.1080/13683500.2020.1803807

Olsen, D.H., \& Timothy, D.J. (2020). The COVID-19 pandemic and religious travel: Present and future trends. International Journal of Religious Tourism and Pilgrimage, 8 (7), 170-188.

Olsen, G., Chowdhury, M., Spector, S., \& Orchiston, C. (2018). Organizational resilience and financial performance. Annals of Tourism Research, 73, 193-196, https://doi.org/10.1016/j.annals.2018.06.006

Richards, G., \& Morrill, W. (2021). The challenge of COVID-19 for youth travel. Revista Brasileiros de Estudos Turísticos, 11, 1-8.

Rogerson, C.M., \& Baum, T. (2020). COVID-19 and African tourism research agendas. Development Southern Africa, 37 (5), $727-741$.

Rogerson, C.M., \& Rogerson, J.M. (2019). Tourism, local economic development and inclusion: evidence from Overstrand Local Municipality, South Africa. GeoJournal of Tourism and Geosites, 25 (2), 293-308. https://doi.org/10.30892/gtg.25202-360

Rogerson, C.M., \& Rogerson, J.M. (2020a). COVID-19 tourism impacts in South Africa: government and industry responses. GeoJournal of Tourism and Geosites, 31 (3), 1083-1091, https://doi.org/10.30892/gtg.31321-544

Rogerson, C.M., \& Rogerson, J.M. (2020b). COVID-19 and tourism spaces of vulnerability in South Africa. African Journal of Hospitality, Tourism and Leisure, 9 (4), 382-401.

Rogerson, C.M., \& Rogerson, J.M. (2021a). COVID-19 and changing consumer demand: Research review and policy implications for South Africa. African Journal of Hospitality, Tourism and Leisure, 10 (1), 1-21.

Rogerson, C.M., \& Rogerson, J.M. (2021b). Creative networks and the making of Africa's first UNESCO Creative City of Gastronomy. In C.M. Rogerson \& J.M. Rogerson Eds. Urban Tourism in the Global South: South African Perspectives. Cham, Switzerland: Springer Nature.

Saarinen, J., \& Wall-Reinius, S. (2021). Tourism Enclaves: Geographies of Exclusive Spaces in Tourism. Abingdon: Routledge.

Sánchez-Cañizares, S.M., Cabeza-Ramírez, L.J., Muñoz-Fernández-G., \& Fuentes-García, F.J. (2020). Impact of the perceived risk from Covid-19 on intention to travel. Current Issues in Tourism. https://doi.org/10.1080/13683500.2020.1829571

Sigala, M. (2020). Tourism and COVID-19: Impacts and implications for advancing and resetting industry and research. Journal of Business Research, 117, 312-321, https://doi.org/10.1016/j.jbusres.2020.06.015

Verma, S., \& Gustafsson, A. (2020). Investigating the emerging COVID-19 research trends in the field of business and management: A bibliometric analysis approach. Journal of Business Research, 118, 253-261.

Zenker, S., \& Kock, F. (2020). The coronavirus pandemic- A critical discussion of a tourism research agenda. Tourism Management, 81,104164

Article history: Received: 11.01.2021 Revised: 08.02.2021 Accepted: 01.04.2021 Available online: 28.04.2021 